\title{
Subprimal Type and Quality Grade Affect Fatty Acid Composition and Cooked Firmness of Ground Beef Patties
}

\section{C.M. Garner, J.A. Unruh, M.C. Hunt, E.A.E. Boyle, T.A. Houser, and S. Stroda}

\section{Introduction}

Beef tenderness, juiciness, and flavor contribute to consumer satisfaction and therefore price differentiation of beef products. Ground beef is the most commonly consumed beef product in the United States. Historically, the source of ground beef comes from lower quality cuts, trimmings from subprimals, and subprimals from cull cows; however, alternative grinds from whole and/or premium quality subprimals are becoming more popular with consumers. Subprimals from the chuck and round are logical subprimals that could be used for premium ground beef production because they cost less than other subprimals, such as those from the rib and loin. Ground beef products from higher quality grades such as Premium Choice (upper two-thirds of Choice) offer merchandising potential and are commonly utilized as a higher-quality product. The inherent lean and fat property differences that may exist in these subprimals could potentially influence palatability of the resulting ground beef products.

Subprimals can be stored in a vacuum package for extended periods of time at low storage temperatures. The number of days that subprimals may be held before processing can be influenced by the distribution chain, accessibility, and subprimal price fluctuations. Extended vacuum storage before grinding could affect biochemical, oxidative, and microbial properties of these subprimals and influence sensory properties. Our objective was to determine the effects of two subprimal types (chuck roll and knuckle), two quality grades (Premium Choice and Select), and three vacuum-packaged storage aging times before processing $(7,21$, and 42 days) on ground beef patty sensory properties.

\section{Experimental Procedures}

At the end of each aging time $(7,21$, or 42 days), four knuckles or two chuck rolls representing their respective quality grade categories (upper two-thirds of Choice and Select), were combined and ground using a 3/8-in. plate to form a treatment or sample batch. Six replications were made for each of the 12 treatment combinations. After the second final grind using a 1/8-in. plate, fatty acid analyses were conducted on raw ground beef samples. For sensory panels and instrumental tenderness (slice shear force, textural profile analysis, and Lee-Kramer shear), 1/4-lb patties were formed using a Hollymatic patty machine, crust-frozen at $-40^{\circ} \mathrm{F}$ before vacuum-packaging, and stored at $-4^{\circ} \mathrm{F}$. Patties were thawed at $36^{\circ} \mathrm{F}$ for 24 hours and cooked on a griddle to an internal endpoint temp of $160^{\circ} \mathrm{F}$. For sensory panels, cooked patties were cut into eight wedge slices and evaluated by a trained sensory panel. Trained sensory panelists used a scale of 1 to 8 to evaluate firmness $(1=$ extremely soft, $8=$ extremely firm $)$, cohesiveness $(1=$ not cohesive at all, $8=$ extremely cohesive), juiciness $(1=$ extremely dry, $8=$ extremely juicy), beef flavor intensity ( $1=$ extremely bland, $8=$ extremely intense), mouth coat 
( 1 = abundant, $8=$ none $)$, off-flavor $(1=$ abundant, $8=$ none $)$, and desirability $(1=$ extremely dislike, 8 = extremely like).

To determine instrumental properties, the cooked patties were cooled to room temperature for approximately 30 minutes before the measurements were taken. For slice shear force, two 1.2-in. strips were removed from each patty, and each strip was sheared twice. Two patties per sample were utilized, resulting in eight measurements that were averaged for analysis. The blade was attached to the crosshead of an Instron with a 220-lb load cell and crosshead speed of $9.8 \mathrm{in} . /$ minute.

To determine Lee-Kramer shear values, two cooked patties from each sample were cut into $2.4 \times 2.4$-in. subsamples, weighed, and sheared in the Lee-Kramer cell attached to the Instron with a 220-lb load cell and a crosshead speed of $13.8 \mathrm{in} / \mathrm{minute}$. Peak force was determined and divided by the sample weight to obtain force/oz. The average of the two patty measurements was used for analysis.

For texture profile analysis, three 1-in.-diameter cores were removed perpendicular to the flat surface of each of two cooked patties from each sample. Each core was compressed to $30 \%$ of its height for two cycles. We used an Instron with a $220-1 b$ load cell and a crosshead speed of $7.9 \mathrm{in} /$ minute. Sample averages for hardness (peak force of first compression), peak force of the second compression, cohesiveness (total energy of second compression $\div$ total energy of the first compression), springiness (base depth of second compression $\div$ base depth of first compression), and gumminess (hardness $\times$ cohesiveness) were used for statistical analysis.

\section{Results and Discussion}

In a subprimal type $\times$ quality grade interaction, Premium Choice chuck roll subprimals $(19.6 \%)$ had $(P<0.05)$ the highest percentage of total fatty acids per lb of tissue, and those from Select knuckle subprimals $(5.9 \%)$ had $(P<0.05)$ the lowest percentage. In addition, Select chuck roll subprimals $(13.8 \%)$ had $(P<0.05)$ higher percentages of total fatty acids than Premium Choice knuckle subprimals (8.2\%). Ground beef samples from chuck roll subprimals had $(P<0.05)$ greater percentages of saturated fatty acids (SFA) and lower percentages of polyunsaturated fatty acids (PUFA) than those from knuckle subprimals (Table 1). As a result, ground beef samples from chuck roll subprimals had $(P<0.05)$ lower monounsaturated (MUFA):SFA and PUFA:SFA ratios than those from knuckle subprimals. Premium Choice subprimals had $(P<0.05)$ higher percentages of MUFA (primarily oleic acid) than those from Select subprimals; however, Select subprimals had $(P<0.05)$ greater percentages of SFA and PUFA than those from Premium Choice subprimals. As a result, Premium Choice subprimals had $(P<0.05)$ higher MUFA:SFA ratios and lower PUFA:SFA ratios than Select subprimals.

For ground beef patties from chuck roll subprimals, sensory panelists found those from Select subprimals were $(P<0.05)$ firmer and had $(P<0.05)$ less mouth coating (higher scores) than those from Premium Choice subprimals (Table 2). For ground beef patties from knuckle subprimals, those from Premium Choice and Select subprimals had $(P>0.05)$ similar scores for all sensory panel traits. 
For instrumental tenderness measures of slice shear force and Lee-Kramer shear, ground beef patties from knuckle subprimals had $(P<0.05)$ greater peak force values than those from chuck roll subprimals (Table 3 ). In addition, ground beef patties from Select subprimals had $(P<0.05)$ greater peak force values than those from Premium Choice subprimals. Furthermore, ground beef patties from subprimals aged 7 days had $(P<$ $0.05)$ greater peak force values than those from subprimals aged for 21 and 42 days.

For texture profile analysis, ground beef patties from knuckle subprimals had $(P<0.05)$ greater hardness (first compression peak force), gumminess, and springiness than those from chuck roll subprimals. Ground beef patties from Select subprimals had $(P<0.05)$ greater hardness values than those from Premium Choice subprimals. Patties aged 42 days had $(P<0.05)$ greater hardness than those aged 7 days, and springiness declined with increased aging.

Overall, patties from fatter chuck roll and Premium Choice subprimals were softer (lower peak forces and hardness) than those from knuckle and Select subprimals, respectively. This difference was observed by a sensory panel for patties from chuck rolls in which those from Select subprimals were firmer.

\section{Implications}

Patties from Premium Choice chuck rolls provide the softest characteristics to the palate and instrumentally, whereas those from Select knuckles provide the greatest firmness and instrumental resistance.

\section{Acknowledgement}

This work was funded by The Beef Checkoff.

Table 1. Effect of subprimal type and quality grade on the percentages (expressed as percentage of total fatty acids ${ }^{1}$ ) and ratios for fatty acid categories of ground beef patties

\begin{tabular}{|c|c|c|c|c|c|c|}
\hline \multirow[b]{2}{*}{ Trait $^{4}$} & \multicolumn{3}{|c|}{ Subprimal type ${ }^{2}$} & \multicolumn{3}{|c|}{ Quality grade ${ }^{3}$} \\
\hline & CR & $\mathrm{KN}$ & SE & $\mathrm{PCH}$ & SEL & SE \\
\hline SFA (\%) & $46.8^{b}$ & $45.0^{\mathrm{a}}$ & 0.3 & $45.3^{\mathrm{a}}$ & $46.5^{b}$ & 0.3 \\
\hline MUFA (\%) & 49.4 & 49.9 & 0.6 & $50.6^{\mathrm{b}}$ & $48.7^{\mathrm{a}}$ & 0.6 \\
\hline PUFA (\%) & $3.77^{\mathrm{a}}$ & $5.07^{\mathrm{b}}$ & 0.39 & $4.03^{\mathrm{a}}$ & $4.81^{\mathrm{b}}$ & 0.39 \\
\hline MUFA:SFA ratio & $1.06^{\mathrm{a}}$ & $1.11^{\mathrm{b}}$ & 0.02 & $1.12^{\mathrm{b}}$ & $1.05^{\mathrm{a}}$ & 0.02 \\
\hline PUFA:SFA ratio & $0.08^{\mathrm{a}}$ & $0.11^{\mathrm{b}}$ & 0.01 & $0.09^{a}$ & $0.11^{\mathrm{b}}$ & 0.01 \\
\hline
\end{tabular}

${ }^{1}$ Total fatty acids (gm/100 gm tissue): PCH CR (19.6) > SEL CR (13.8) > PCR KN (8.2) > SEL KN (5.9).

${ }^{2}$ Subprimal type: $\mathrm{CR}=$ chuck roll; $\mathrm{KN}=$ knuckle.

${ }^{3}$ Quality grade: $\mathrm{PCH}=$ Premium Choice; $\mathrm{SEL}=$ Select.

${ }^{4} \mathrm{SFA}=$ saturated fatty acids; MUFA = monounsaturated fatty acids; PUFA = polyunsaturated fatty acids.

a,b Means within a row and main effect with a different superscript letter $\operatorname{differ}(P<0.05)$. 
MEAT AND FOOD SAFETY

Table 2. Effect of quality grade and aging time on sensory traits for ground beef patties

\begin{tabular}{|c|c|c|c|c|c|c|c|}
\hline \multirow[b]{2}{*}{ Trait $^{1}$} & \multicolumn{3}{|c|}{ Quality grade } & \multicolumn{4}{|c|}{ Aging time (days) } \\
\hline & $\begin{array}{c}\text { Premium } \\
\text { Choice }\end{array}$ & Select & SE & 7 & 21 & 42 & SE \\
\hline \multicolumn{8}{|l|}{ Chuck roll } \\
\hline Firmness & $4.7^{\mathrm{a}}$ & $4.9^{b}$ & 0.07 & 4.8 & 4.7 & 4.8 & 0.08 \\
\hline Cohesiveness & 4.8 & 4.9 & 0.07 & 4.9 & 4.8 & 4.9 & 0.08 \\
\hline Juiciness & 5.5 & 5.3 & 0.11 & 5.4 & 5.4 & 5.5 & 0.13 \\
\hline Beef flavor & 5.3 & 5.3 & 0.10 & 5.1 & 5.4 & 5.4 & 0.11 \\
\hline Mouth coat & $6.7^{\mathrm{a}}$ & $6.8^{\mathrm{b}}$ & 0.06 & 6.8 & 6.8 & 6.8 & 0.07 \\
\hline Off-flavor & 7.6 & 7.6 & 0.10 & $7.3^{\mathrm{a}}$ & $7.8^{\mathrm{b}}$ & $7.8^{\mathrm{b}}$ & 0.12 \\
\hline Desirability & 5.4 & 5.4 & 0.12 & 5.2 & 5.5 & 5.4 & 0.13 \\
\hline \multicolumn{8}{|l|}{ Knuckle } \\
\hline Firmness & 5.0 & 5.1 & 0.09 & 5.1 & 4.9 & 5.0 & 0.09 \\
\hline Cohesiveness & 4.9 & 5.0 & 0.07 & 5.0 & 4.9 & 5.1 & 0.08 \\
\hline Juiciness & 5.1 & 5.2 & 0.10 & $4.8^{\mathrm{a}}$ & $5.1^{\mathrm{b}}$ & $5.5^{c}$ & 0.11 \\
\hline Beef flavor & 5.3 & 5.2 & 0.06 & 5.1 & 5.2 & 5.3 & 0.07 \\
\hline Mouth coat & 7.0 & 7.1 & 0.04 & $7.2^{\mathrm{c}}$ & $7.0^{\mathrm{b}}$ & $6.9^{\mathrm{a}}$ & 0.05 \\
\hline Off-flavor & 7.7 & 7.6 & 0.09 & $7.5^{\mathrm{a}}$ & $7.8^{\mathrm{b}}$ & $7.5^{\mathrm{a}}$ & 0.09 \\
\hline Desirability & 5.2 & 5.0 & 0.11 & $4.8^{\mathrm{a}}$ & $5.2^{\mathrm{b}}$ & $5.3^{\mathrm{b}}$ & 0.12 \\
\hline
\end{tabular}

${ }^{1}$ Firmness $(1=$ extremely soft, $8=$ extremely firm $)$; cohesiveness $(1=$ not cohesive, $8=$ extremely cohesive); juiciness $(1=$ extremely dry, 8 = extremely juicy); beef flavor intensity $(1=$ extremely bland, $8=$ extremely intense); mouth coat $(1=$ abundant, $8=$ none); off-flavor intensity ( $1=$ abundant, $8=$ none); desirability $(1=$ extremely dislike, $8=$ extremely like).

${ }^{\mathrm{a}-\mathrm{c}}$ Means within a row and main effect with a different superscript letters $\operatorname{differ}(P<0.05)$.

Table 3. Effects of subprimal type, quality grade, and aging time for instrumental tenderness traits for ground beef patties

\begin{tabular}{|c|c|c|c|c|c|c|c|c|c|c|}
\hline & \multicolumn{3}{|c|}{ Subprimal type ${ }^{1}$} & \multicolumn{3}{|c|}{ Quality grade ${ }^{2}$} & \multicolumn{4}{|c|}{ Aging time (days) } \\
\hline & CR & $\mathrm{KN}$ & SE & $\mathrm{PCH}$ & SEL & SE & 7 & 21 & 42 & SE \\
\hline \multicolumn{11}{|l|}{ Slice shear force } \\
\hline Peak force (lb) & $5.97^{a}$ & $7.10^{\mathrm{b}}$ & 0.16 & $6.28^{\mathrm{a}}$ & $6.79^{\mathrm{b}}$ & 0.16 & $7.34^{\mathrm{b}}$ & $6.02^{\mathrm{a}}$ & $6.24^{a}$ & 0.20 \\
\hline \multicolumn{11}{|l|}{ Lee-Kramer shear force } \\
\hline Peak force (lb/oz) & $161.3^{\mathrm{a}}$ & $195.6^{\mathrm{b}}$ & 2.6 & $168.1^{\mathrm{a}}$ & $188.8^{\mathrm{b}}$ & 2.6 & $195.5^{\mathrm{b}}$ & $175.6^{a}$ & $167.5^{\mathrm{a}}$ & 3.2 \\
\hline \multicolumn{11}{|c|}{ Texture profile analysis ${ }^{3}$} \\
\hline Hardness (lb) & $7.83^{\mathrm{a}}$ & $8.93^{\mathrm{b}}$ & 1.03 & $8.07^{\mathrm{a}}$ & $8.66^{\mathrm{b}}$ & 1.03 & $8.14^{\mathrm{a}}$ & $8.25^{\mathrm{ab}}$ & $8.73^{\mathrm{b}}$ & 1.04 \\
\hline 2nd peak force (lb) & $7.03^{\mathrm{a}}$ & $8.18^{\mathrm{b}}$ & 0.91 & $7.32^{\mathrm{a}}$ & $7.89^{\mathrm{b}}$ & 0.91 & 7.41 & 7.50 & 7.89 & 0.92 \\
\hline Cohesiveness & 0.55 & 0.67 & 0.09 & 0.66 & 0.56 & 0.09 & 0.56 & 0.55 & 0.72 & 0.11 \\
\hline Gumminess (lb) & $4.12^{\mathrm{a}}$ & $4.48^{b}$ & 0.29 & 4.21 & 4.41 & 0.29 & 4.30 & 4.23 & 4.39 & 0.30 \\
\hline Springiness & $4.03^{\mathrm{a}}$ & $3.68^{b}$ & 0.05 & 3.87 & 3.84 & 0.05 & $4.20^{c}$ & $3.91^{\mathrm{b}}$ & $3.46^{\mathrm{a}}$ & 0.06 \\
\hline
\end{tabular}

${ }^{1}$ Subprimal type: $\mathrm{CR}=$ chuck roll; $\mathrm{KN}=$ knuckle.

${ }^{2}$ Quality grade: $\mathrm{PCH}=$ Premium Choice; $\mathrm{SEL}=$ Select.

${ }^{3}$ Hardness (peak force of first compression); 2nd peak force (peak force of the second compression); cohesiveness (total energy of second compression $\div$ total energy of the first compression); gumminess (hardness $\times$ cohesiveness); springiness (depth of second compression $\div$ depth of first compression).

${ }^{a-c}$ Means within a row and main effect with a different superscript letter differ $(P<0.05)$. 